\title{
PENGARUH PEMBERIAN SILASE LIMBAH IKAN TERHADAP LEMAK ABDOMINAL DAN LEMAK DAGING PADA BEBEK PEDAGING
}

\author{
The Effect of Giving Fish Waste Silage on Abdominal Fat and Meat Fat of \\ Duck
}

\author{
Mei Sulistyoningsih ${ }^{1}$, Reni Rakhmawati ${ }^{2 *}$, Atip Nurwahyunani ${ }^{3}$, Karina Rinanda Priscilla ${ }^{4}$ \\ Program Studi Pendidikan Biologi, FPMIPATI, Universitas PGRI Semarang \\ Email : rahmamashuri@yahoo.com
}

\begin{abstract}
The purpose of this study to determine the effect of giving silage of fish waste to level of meat fat and the abdominal fat of duck in magelang. The role of duck farming is very important to provide the protein of Indonesian people for meat and eggs. The use of feeding ingredients that are easily available at relatively cheaper prices but still good nutritional content for the production, one of them is by utilizing silage of fish waste. Fish waste silage also contains the necessary ingredients for ducks. The design used in this study was a completely randomized design (CRD). The study consisted of 3 treatments there are PO (control), P1 (fish silage 5\%), P2 (fish silage 10\%) and 4 repetitions. The analysis using one-way ANOVA with a level of 5\%, if there is a difference, then Duncan's Multiple Distance Test is performed. The results showed that silage application of fish waste did not significantly affect the fat content of meat $(P>0.05)$. There was no significant effect on abdominal fat levels $(P>0.05)$. The result showed that the addition of fish silage food resulted the normal level of meet fat and abdominal fat.

Keywords: Magelang duck, level of meat fat and the abdominal fat of duck, fish waste silage.
\end{abstract}

\begin{abstract}
ABSTRAK
Tujuan penelitian ini mengetahui pengaruh pemberian silase limbah ikan terhadap kadar lemak daging dan lemak abdominal bebek magelang. Peranpeternakan bebek sangatpentinguntuk menyediakankebutuhan proteindagingdantelur masyarakat Indonesia. Pemanfaatan bahan pakan yang mudah didapat dengan harga yang relatif lebih murah tetapi masih mempunyai kandungan gizi yang baik untuk produksi salah satunya memanfaatkan silase limbah ikan. Silase limbah ikan juga memliki kandungan yang diperlukan pada bebek. Rancangan yang digunakan dalam penelitian ini yaitu Rancangan Acak Lengkap (RAL). Penelitian yang terdiri atas 3 perlakuan P0(kontrol), P1(silase ikan 5\%), P2(silase ikan 10\%) dan 4 kali pengulangan. Analisis menggunakan ANOVA satu arah dengan taraf 5\%, bila terdapat perbedaan, kemudian dilakukan Uji Jarak Berganda Duncan. Hasil penelitian menunjukkan bahwa pemberian silase limbah ikan tidak berpengaruh nyata terhadap kadar lemak daging $(\mathrm{P}>0,05)$. Tidak berpengaruh nyata terhadap kadar lemak abdominal $(\mathrm{P}>0,05)$. Hasil penelitian menunjukkan bahwa penambahan pakan silase limbah ikan menghasilkan kadar normal pada persentase bobot organ dalam bebek.

Kata kunci : Bebek Magelang, kadar lemak daging dan lemak abdominal bebek, silase limbah ikan.
\end{abstract}

\section{PENDAHULUAN}

Itik merupakan unggas air yang dipelihara sebagai penghasil telur dan daging. Peran itik sebagai penyedia daging pada tahun 2016 adalah sebesar 36.350 ton (Ditjennak, 2016). Kebutuhan masyarakat akan konsumsi daging sebagai sumber protein hewani semakin meningkat setiap tahunnya.
Itik pedaging merupakan ternak unggas penghasil daging yang sangat potensial di samping ayam. Kelebihan ternak ini adalah lebih tahan terhadap penyakit dibandingkan dengan ayam ras sehingga pemeliharaannya mudah dan tidak banyak mengandung resiko. Daging itik merupakan sumber protein yang bermutu tinggi dan itik mampu berproduksi dengan baik, oleh karena itu pengembangannya diarahkan kepada produksi yang cepat dan 


\section{JURNAL ILMIAH AGRINECA \\ ISSN : 2721-074X (Online) - 2301-6698 (Print)}

Available on : http://ejournal.utp.ac.id/index.php/AFP/index

This is Under CC BY SA Licence

tinggi sehingga mampu memenuhi permintaan konsumen (Ali dan Febrianti, 2009).

Daging itik mempunyai kandungan gizi yang tinggi seperti kandungan protein, lemak dan mineral yang dibutuhkan oleh tubuh (Ambarwati et al., 2012). Itik termasuk jenis unggas yang memiliki potensi besar sebagai sumber protein hewani. Pada tahun 2015, industri peternakan menghasilkan sekitar 2.925.210 ton daging dengan pemasok daging terbesar yaitu daging ayam ras $(56 \%)$, daging sapi $(17 \%)$, daging ayam buras $(10 \%)$ dan lainlain (17\%), sedangkan kontribusi daging itik hanya sekitar 38.840 ton atau hanya sebesar $1.32 \%$ dari total produksi daging Indonesia (Ditjennak, 2015).

Kandungan lemak yang tinggi pada kulit yang berperan sebagai isolator terhadap dingin karena itik juga merupakan unggas air, namun kandungan lemak yang tinggi pada itik menyebabkan masyarakat kurang menyukai untuk mengonsumsi daging itik karena dikhawatirkan dapat memicu penyakit. Sumber deposit lemak daging salah satunya berasal dari pakan oleh karena itu dibutuhkan ransum dengan bahan yang dapat menekan timbunan lemak tersebut salah satunya adalah asam lemak tak jenuh.

\section{METODE PENELITIAN}

\section{Subjek Penelitian}

Subjek penelitian yang dilakukan yaitu menggunakan DOC bebek magelang sebanyak 200 ekor. Penelitian ini dilaksanakan pada Juli

Tabel 1. Hasil Rerata Lemak Daging pada bebek
- November 2019. Lokasi penelitian berada di Mranggen, Demak.

\section{Alat dan Bahan}

Alat penelitian : pisau, label nama, timbangan, tempat pakan, tempat minum Bahan penelitian : bebek 200 ekor, silase limbah ikan, asam laktat, pakan komersial.

\section{Desain Penelitian}

Jenis penelitian ini menggunakan penelitian eksperimen dengan desain Rancangan Acak Lengkap (RAL). Penelitian ini terdiri 3 perlakuan dengan 4 pengulangan. Setiap jenis perlakuan diambil 4 ekor bebek sebagai ulangan sehingga jumlah total sampel penelitian 12 ekor bebek.

Perlakuan penelitian ini terdiri dari :

P0 : pakan komersial (kontrol)

$\mathrm{P} 1$ : pakan komersial $+5 \%$ silase ikan

$\mathrm{P} 2$ : pakan komersial $+10 \%$ silase ikan

\section{Analisis dan Interpretasi Data}

Analisis data mencakup homogenitas, normalitas sampel penelitian. Analisis akhir dengan ANOVA dengan taraf signifikan 5\%, bila ada pengaruh dilanjutkan dengan UJGD.

\section{HASIL DAN PEMBAHASAN}

Hasil penelitian pengaruh pemberian silase limbah ikan terhadap lemak daging dan lemak abdominal pada bebek magelang ssebagai berikut :

\section{a. Kadar Lemak Daging pada Bebek}

\begin{tabular}{ccccccc}
\hline Perlakuan & \multicolumn{7}{c}{ Ulangan Ke- } & JumlahPerlakuan & Rataan perlakuan \\
& 1 & 2 & 3 & 4 & 29,45 & $7,362^{\mathrm{a}}$ \\
\hline P0 & 7,35 & 9,06 & 6,78 & 6,26 & 28,64 & $7,16^{\mathrm{a}}$ \\
P1 & 7,31 & 6,53 & 7,89 & 6,91 & 29,66 & $7,415^{\mathrm{a}}$ \\
P2 & 7,66 & 8,37 & 7,30 & 6,33 & 87,75 & 7,312 \\
\hline jumlah & 22,32 & 23,96 & 21,97 & 19,5 & \\
\hline \multicolumn{7}{c}{ Rataan ulangan } \\
\hline
\end{tabular}

Sumber : analisis data primer, 2020 
Keterangan: Nilai denganhurufSuperskript yang sama, pada kolom yang samadengan baris berbeda menunjukkan hasil yang berbedanyata $(\mathrm{P}<0,05)$

a : tidak beda nyata

Hasil penelitian pengaruh pemberian silase limbah ikan terhadapkadar lemak dagingdiketahuiF hitung $(0,125)<\mathrm{F}$ tabel $5 \%$ $(4,26)$ dan $F$ tabel $1 \% \quad(8,02)$. Reratapresentasekadar lemak daging pada bebekyaitu P0 pada bebek (7,362 g/dl), sedangkan P1 dengan penambaha nsilase ikan $5 \%(7,16 \mathrm{~g} / \mathrm{dl}), \mathrm{P} 2$ dengan penambahan silase ikan $10 \%(7,415 \mathrm{~g} / \mathrm{dl})$, Hal ini menunjukkan bahwa H0 tidak ada pengaruh pemberian silase limbah ikan terhadap kadar lemak daging pada bebek pedaging diterima sedangkan $\mathrm{H} 1$ yang menyatakan ada pengaruh pemberian pakan silase limbah ikan terhadap kadar lemak daging pada bebek pedaging ditolak.

Pada table hasil penelitian menunjukkan kadar lemak daging yaitu berkisar 7,362 g/dl sampai 87,75 g/dl. Pakan dalam peternakan sangat berpengaruh terhadap pertumbuhan ternak terutama terhadap perkembangan fisiologis ternak. Dalam penelitian ini hasil yang didapatkan menunjukkan hasil yang relatif sama antar perlakuan. Dikarenakan selisih pemberian pakan silase limbah ikan sebagai perlakuan tidak jauh berbeda antar tiap perlakuan. Sehingga kandungan lemak daging pada bebek tidak jauh berbeda tiap perlakuannya.

Lemak daging bebek diproduksi melalui konsumsi pakan yang mengandung lemak, karbohidrat, dan protein dalam ransum, didalam silase limbah ikan itu sendiri mengandung protein kasar yang berkisar 15,493\% sedangkan dalam pakan komersial 21-23\% (Sulistyoningsih, 2015).

Menurut Suparyanto (2005), di dalam tubuh bebek sebagian lemak, karbohidrat, dan protein akandicerna oleh bebek, apabila produksinya berlebihan akan diubah menjadi lemak dan lemak tersebut akan disimpan di dalam tubuhnya. Kandungan lemak diperoleh melalui kelebihan energi yang berlebihan, apabila pakan yang dikonsumsi mengandung banyak lemak maka lemak yang dihasilkan bebek akan banyak pula.
P0: Kontrol

P1: Pakansilaselimbah ikan 5\%

P2: Pakansilaselimbah ikan 10\%

\section{b. Hasil Kadar Lemak Abdominal pada Bebek}

Hasil penelitian pengaruh pemberian silase limbah ikan terhadap kadar lemak abdominal diketahui $\mathrm{F}$ hitung $(1,634)<\mathrm{F}$ tabel $5 \%(4,26)$ dan $\mathrm{F}$ tabel $1 \%(8,02)$. Rerata presentase kadar lemak abdominal pada bebek yaitu P0 pada bebek $(3,25 \mathrm{~g} / \mathrm{dl})$, sedangkan P1 dengan penambahan silase ikan $5 \%(5,25 \mathrm{~g} / \mathrm{dl})$, P2 dengan penambahan silase ikan $10 \%(4,5$ g/dl), hal ini menunjukkan bahwa H0 tidak ada pengaruh pemberian silase limbah ikan terhadap kadar lemak abdominal pada bebek pedaging diterima sedangkan $\mathrm{H}_{1}$ yang menyatakan ada pengaruh pemberian pakan silase limbah ikan terhadap kadar lemak abdominal pada bebek pedaging ditolak.

Penelitian ini menunjukkan hasil yang relatif sama pada setiap perlakuan pemberian silase limbah ikan terhadap bebek dengan perkataan lain tidak ada perbedaan antara perlakuan terhadap kadar glukosa darah, disebabkan oleh kandungan energi metabolis yang sama untuk setiap masing-masing perlakuan dalam penelitian ini berkisar antara 2000- 3000 (Kal/g). Energi metabolis yang terkandung dalam silase ikan berkisar 3593,67 (Kal/g), sedangkan dalam pakan komersial berkisar 3000-3500 (Kal/g) (Sulistyoningsih, 2015), dalam pembuatan silase ikan menambahkan dedak untuk mengurangi kadar air yang ada di dalam silase.

Dedak padi mengandung protein kasar $12,0 \%$, serat kasar $13,82 \%$, kalsium $0,20 \%$, fosfor $1,10 \%$ dan energi metabolis 2.400 (Kal/g) (Sinurat dalam, Ketaren 2002). Dedak (bran) merupakan hasil samping dari proses penggilingan padi pada lapisan luar maupun dalam dari butiran padi, jumlahnya sekitar $10 \%$ dari jumlah padi yang digiling menjadi beras dan energi yang terkandung dalam dedak padi bisa mencapai $2980 \mathrm{kkal} / \mathrm{kg}$. Dedak padi memiliki bau khas wangi dedak, jika baunya sudah tengik berarti telah terjadi reaksi kimia (Dharmawati et al. 2014). 


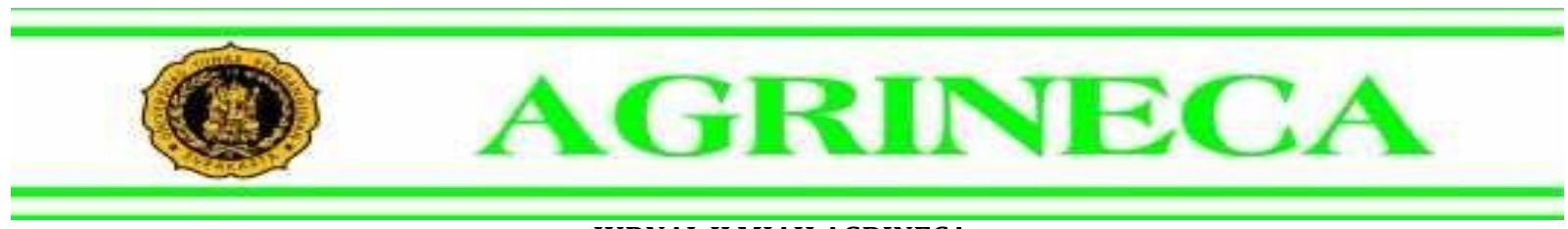

JURNAL ILMIAH AGRINECA

ISSN : 2721-074X (Online) - 2301-6698 (Print)

Available on : http://ejournal.utp.ac.id/index.php/AFP/index

This is Under CC BY SA Licence

Tabel 2. Hasil Rerata Lemak Abdominal pada bebek

\begin{tabular}{|c|c|c|c|c|c|c|}
\hline \multirow[t]{2}{*}{ Perlakuan } & \multicolumn{4}{|c|}{ Ulangan Ke- } & \multirow[t]{2}{*}{ Jumlah Perlakuan } & \multirow[t]{2}{*}{ Rataan perlakuan } \\
\hline & 1 & 2 & 3 & 4 & & \\
\hline P0 & 3 & 4 & 2 & 4 & 13 & $3,25^{\mathrm{a}}$ \\
\hline $\mathrm{P} 1$ & 6 & 6 & 4 & 5 & 21 & $5,25^{\mathrm{a}}$ \\
\hline $\mathrm{P} 2$ & 3 & 4 & 8 & 3 & 21 & $4,5^{\mathrm{a}}$ \\
\hline jumlah & 12 & 14 & 14 & 12 & 52 & \\
\hline \multicolumn{6}{|c|}{ Rataan ulangan } & 4,33 \\
\hline
\end{tabular}

Sumber : Analisis data primer, 2020

Keterangan: Nilai dengan huruf Superskript yang sama, pada kolom yang sama dengan baris berbeda menunjukkan hasil yang berbeda nyata $(\mathrm{P}<0,05)$

Keterangan:

Konsumsi ransum dipengaruhi oleh kebutuhan energi dan kandungan energi ransum, apabila kebutuhan energinya sudah tercukupi maka konsumsi akan sedikit dan sebaliknya (Rasyaf, 2002), apabila kandungan energi dalam ransum tinggi maka konsumsi pakan akan turun dan sebaliknya apabila kandungan energi ransum rendah, maka konsumsi pakan akan naik guna memakai kebutuhan energi. Dewanti dkk.(2013), juga menambahkan bahwa lemak abdominal juga dipengaruhi oleh pakan dan umur.

\section{KESIMPULAN}

Hasil penelitian lemak daging pada bebek tidak berbeda nyata pada perlakuan P0 7,362\%, P1 (silase 5\%) 7,16\%, P2 (silase 10\%) 7,415\%. Hasil penelitian lemak abdominal pada bebek tidak berbeda nyata pada perlaku P0 3,25\%, P1 (silase 5\%) 5,25\%, P2 (silase 10\%) 4,5\%.

\section{DAFTAR PUSTAKA}

Ali, A. dan Febrianti, N. 2009. Performans itik pedaging (lokal $\mathrm{x}$ peking) fase starter pada tingkat kepadatan kandang yang berbeda di desa laboi jaya kabupaten kampar. Jurnal Peternakan Vol 6 No 1 Februari 2009 (29 - 35) ISSN 1829 - 8729. Pekanbaru.

Dewanti, R,, M. Irham dan Sudiyono. 2013. Pengaruh penggunaan eceng gondok (Eichornia crassipes) terfermentasi dalam ransum terhadap persentase karkas, nonkarkas dan lemak abdominal itik lokal jantan umur delapan minggu, Buletin Peternakan. 37(1):19-25
P0: Kontrol

P1: Pakan silase limbah ikan 5\%

P2: Pakan silase limbah ikan 10\%

a : tidak beda nyata

Dharmawati S, Malik A, Rafi'i M. 2014. Tingkat penggunaan dedak sebagai aditif terhadap kualitas fisik dan kadar protein silase limbah ikan. Media Sains 7 (1): 103-112.

Ditjennak. 2015. Statistik Peternakan dan Kesehatan Hewan. Direktoran Jendral Peternakan dan Kesehatan Hewan Kementrian Pertanian RI : Jakarta.

Direktorat Jenderal Peternakan dan Kesehatan Hewan. 2016. Data Populasi dan Produksi Peternakan di Indonesia. Direktoral Jenderal Peternakan dan Kesehatan Hewan Kementerian Pertanian RI.

Sulistyoningsih, M. 2015. Pengaruh Pemberian Silase Limbah Ikan terhadap Kadar Protein Daging dan Lemak Daging Broiler Sebagai Upaya Peningkatan Kualitas Pangan. Pros. Sem Nas Masy Biodiv indon. ISS: 2407- 8050. 1(2): 378-382.

Suparyanto, A. 2005. Peningkatan Produktivitas Daging Itik Melalui Pembentukan Galur Induk. Institut Prtanian Bogor. Bogor.

Rasyaf, M., 2002. Beternak Itik. Edisi ke- 16. Kanisius. Yogyakarta. 